\title{
WPLYW SPOSOBU PODPARCIA SPRĘŻONYCH PŁYT KANAŁOWYCH Z WYPEŁNIONYMI KANAŁAMI NA ICH NOŚNOŚĆ NA ŚCINANIE
}

\begin{abstract}
Norma dotycząca sprężonych płyt kanałowych, jako sposób zwiększenia wytrzymałości płyty na ścinanie, podaje możliwość uwzględnienia wypełnienia wnętrza kanałów betonem. Dotychczasowe wyniki badań wykazały, że nośność na ścinanie płyt kanałowych ulega znacznej redukcji, nawet o 50\% w wyniku podparcia na podporach sprężystych. W artykule zaprezentowano wyniki badań eksperymentalnych, których celem było określenie wpływu wypełnienia przedskrajnych kanałów płyt opartych na podporze sztywnej i odkształcalnej na ich nośność na ścinanie.
\end{abstract}

Słowa kluczowe: ścinanie, płyty kanałowe, podpory sprężyste, płyty z wypełnionymi kanałami.

\section{Wprowadzenie}

Nośność na ścinanie sprężonych płyt kanałowych (HC) określa się w przekrojach zarysowanych oraz niezarysowanych $\mathrm{w}$ wyniku zginania na podstawie przepisów normowych [1] i [2]. Ze względu na technologię produkcji płyt (produkcja na długich torach naciągowych), ich zbrojenie składa się wyłącznie ze zbrojenia podłużnego tj. cięgien sprężających zlokalizowanych $\mathrm{w}$ dolnej części przekroju poprzecznego płyty. Taki sposób zbrojenia płyt powoduje, że ich nośność na ścinanie zależy głownie od wytrzymałości betonu zastosowanego do produkcji elementów. Dodatkowym czynnikiem wpływającym na nośność jest oczywiście sprężenie, które jednak w elementach strunobetonowych przekazywane jest nie od czoła elementu, ale na odcinku transmisji, czyli tym samym, na którym naprężenia ścinające mają największe wartości. W większości przypadków projektowych nośność na ścinanie typowych płyt HC jest wystarczająca. Niemniej jednak, występują sytuacje, w których nośność na ścinanie, limitowana nośnością rozciąganego krzyżulca betonowego w przekroju prefabrykowanym,

\footnotetext{
${ }^{1}$ Przemysław Bodzak, Politechnika Łódzka Katedra Budownictwa Betonowego, Al. Politechniki 6, 90-924 Łódź, tel. 42-631-35-75, e-mail: pbodzak@p.lodz.pl

${ }^{2}$ Łukasz Sowa, Politechnika Łódzka, Katedra Budownictwa Betonowego, al. Politechniki 6, 90-924 Łódź, tel. 42-631-35-75, e-mail: lukasz.sowa@p.lodz.pl
} 
jest zbyt mała. Wtedy norma [2] pozwala zwiększyć nośność płyty poprzez dodatkowe wypełnienie betonem monolitycznym wnętrza kanałów na długości, na której naprężenia ścinające przekraczają wytrzymałość betonu na rozciąganie. Przyjęte w normie podejście zakłada, że nośność na ścinanie płyty kanałowej z wypełnionymi kanałami jest sumą dwóch nośności na ścinanie: prefabrykatu $\left(\mathrm{V}_{\mathrm{Rd}, \mathrm{c}}\right)$ oraz wypełnionych kanałów i jest określona jest wzorem (1).

$$
V_{R d t}=V_{R d, c}+\frac{2}{3} n b_{c} d f_{c t d}
$$

gdzie: $n$ - liczba wypełnionych kanałów,

$f_{c t d}$ - obliczeniowa wytrzymałość na rozciąganie betonu wypełnienia,

$b_{c}$ - szerokość kanałów określana wg rys. 1 .

Norma [2] nie precyzuje jednak wielu zagadnień m. in.:

- które kanały należy wypełniać (skrajne, przedskrajne, środkowe),

- jakiej klasy beton należy zastosować do wypełnienia kanałów,

- czy istnieje górne ograniczenie nośności i czy powinno ono zależeć od wytrzymałości betonu stosowanego do wypełnienia kanałów,

- czy można uwzględnić wpływ zabetonowania wszystkich kanałów,

- czy i ewentualnie na jakich zasadach stosować należy redukcję nośności ze względu na sprężyste podparcie, jak to jest zalecane dla płyt typowych.

Dotychczasowe badania zarówno całych pól stropowych [3] i [4], jak i wydzielonych elementów [6] wykazały, że oparcie płyt kanałowych na podporach sprężystych powoduje istotne zmniejszenie ich nośności na ścinanie w porównaniu z płytami opartymi na podporach sztywnych. Tego, czy wyniki te są również prawdziwe dla elementów z wypełnionymi kanałami, zarówno badania i zapisy normowe, jak i dodatkowe zalecenia [5] jednoznacznie nie precyzują.

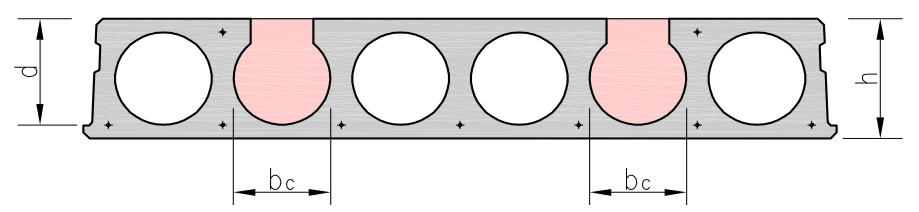

Rys. 1. Przekrój płyty z wypełnionymi kanałami

Fig. 1. Cross section of the Hollow Core with filled hollows

Powszechnie, zarówno w praktyce projektowej, jak i wykonawczej np. ze względów transportowych (konstrukcja uchwytów transportowych) otwierane są kanały przedskrajne. Te otwarte kanały wykorzystywane są również do zakotwienia zbrojenia wymaganego z uwagi na oddziaływania wyjątkowe.

Ponieważ, jak wykazano w pracach [6]-[7], wpływ na zmniejszenie nośności na ścinanie ma również nierównomierny rozdział siły tnącej na poszczególne żebra płyty, nie jest do końca jednoznaczne czy wypełnienie tych kanałów zwiększy nośność na ścinanie w stopniu przewidywanym przez przepisy. 


\section{Opis programu badań}

Problem nośności na ścinanie płyt kanałowych opartych na podporach sprężystych jest przedmiotem prac badawczych i analiz obliczeniowych prowadzonych w Katedrze Budownictwa Betonowego Politechniki Łódzkiej. Program badawczy obejmuje również zagadnienie nośności na ścinanie płyt z wypełnionymi kanałami. W odróżnieniu do badań prezentowanych w [3] i [4], w celu dokładnego opisania mechanizmu zniszczenia płyt, badania prowadzone są na wyizolowanych elementach badawczych, a pomiędzy poszczególnymi seriami badawczymi zakładano tylko jeden parametr zmienny.

\subsection{Opis elementów}

W niniejszym referacie prezentowane są wyniki badań płyt SP 400 z kanałami wypełnionymi betonem $\mathrm{w}$ drugiej fazie po dostarczeniu elementu na miejsce wbudowania. Płyty badane były na podporach sztywnych oraz na podporach sprężystych. Program doświadczalny obejmował badania 5 elementów w skali naturalnej. Szczegółowe wymiary przekroju poprzecznego płyt pokazano na Rys. 2a. Płyty wykonane były z betonu C50/60 a do wypełnienia kanałów użyto betonu klasy C30/37. Zbrojenie dolne płyt składało się z 12 cięgien średnicy 12,5 mm ze stali Y1860S7, a górne z 2 cięgien tej samej średnicy. Siła naciągu każdego cięgna wynosiła $104 \mathrm{kN}$. Kanały otwarto od góry w świeżym betonie, zaraz po uformowaniu płyty. Wnętrza kanałów wypełniono w laboratorium stosując w tym celu beton towarowy.

Wymiary elementów oraz konstrukcję stanowiska badawczego dobrano w taki sposób aby możliwe było zbadanie każdego elementu dwukrotnie. Dzięki
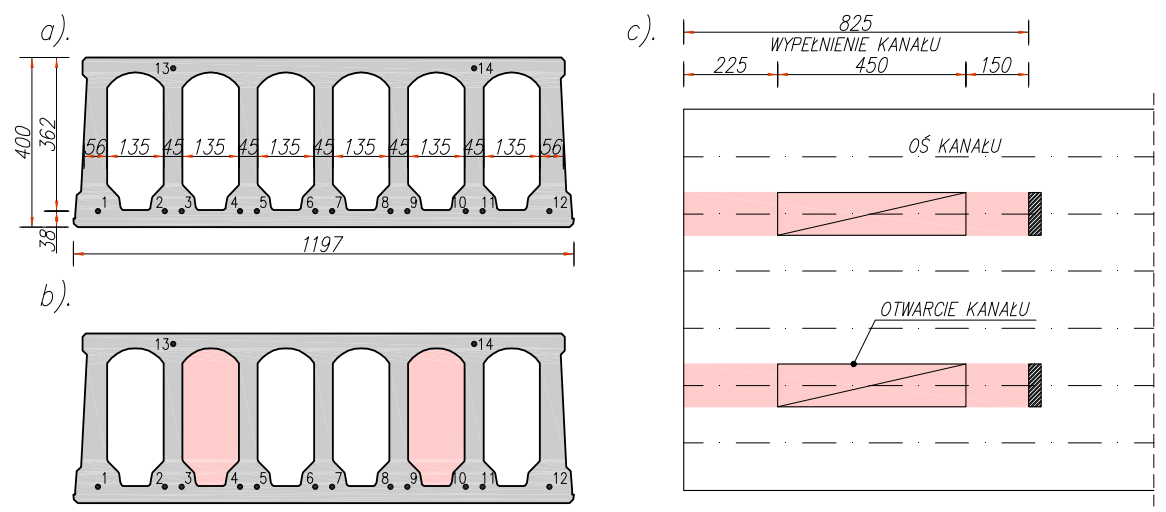

Rys. 2. Elementy badawcze

Fig. 2. Tested elements 
temu, przy zastosowaniu 5 elementów, uzyskano 10 serii badawczych (rys. 3). Elementy podzielono na dwie grupy obejmujące badania na podporach sztywnych i podporach sprężystych. W każdej grupie wykonane zostały elementy bez wypełnionych kanałów i elementy z wypełnionymi przedskrajnymi kanałami (rys. 2b). Długość odcinka, na którym wypełniono kanały pokazano na rys. 2c.

\begin{tabular}{|c|c|c|c|c|c|}
\hline & $\frac{1}{m m}$ & & & 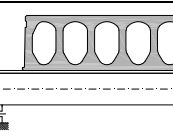 & \\
\hline & & Siła niszcząca & & Siła niszcząca & Ugięcie belki \\
\hline & Oznaczenie & $\mathrm{kN}$ & Oznaczenie & $\mathrm{kN}$ & $\mathrm{mm}$ \\
\hline & SP 400-0-1A & 495,0 & SP 400-I-1A & 365,0 & 6,2 \\
\hline & SP 400-0-1B & 477,0 & SP 400-I-1B & 342,0 & 5,7 \\
\hline & & & SP 400-I-2A & 516,0 & 8,6 \\
\hline & SP 400-0-2A & 636,0 & SP 400-I-2B & 528,0 & 8,3 \\
\hline 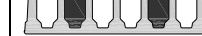 & SP 400-0-2B & 594,0 & SP 400-I-2AA & 447,0 & 7,3 \\
\hline & & & SP $400-\mathrm{I}-2 \mathrm{BB}$ & 516,0 & 8,7 \\
\hline
\end{tabular}

Rys. 3. Program badawczy oraz wielkości obciążenia niszczącego uzyskanego w badaniu

Fig. 3. Research programme and failure load obtained from tests

\subsection{Opis stanowiska badawczego}

Stanowisko do badań płyt na podporze sztywnej (rys. 4a) przygotowano zgodnie z wymaganiami normy [2]. Rozpiętość obliczeniowa płyty wynosiła $4800 \mathrm{~mm}=12 h$ ( $h$ - wysokość przekroju poprzecznego płyty) a odległość między osią podpory a punktem przyłożenia obciążenia $1000 \mathrm{~mm}=2,5 h$. Obciążenie realizowano przy użyciu trzech siłowników hydraulicznych za pośrednictwem sztywnego trawersu (przekrój skrzynkowy na bazie HEB 120). W elementach badanych na podporze sprężystej, aby wyeliminować udział stalowego trawersu w przenoszeniu oddziaływań w kierunku poprzecznym, trawers został podzie-
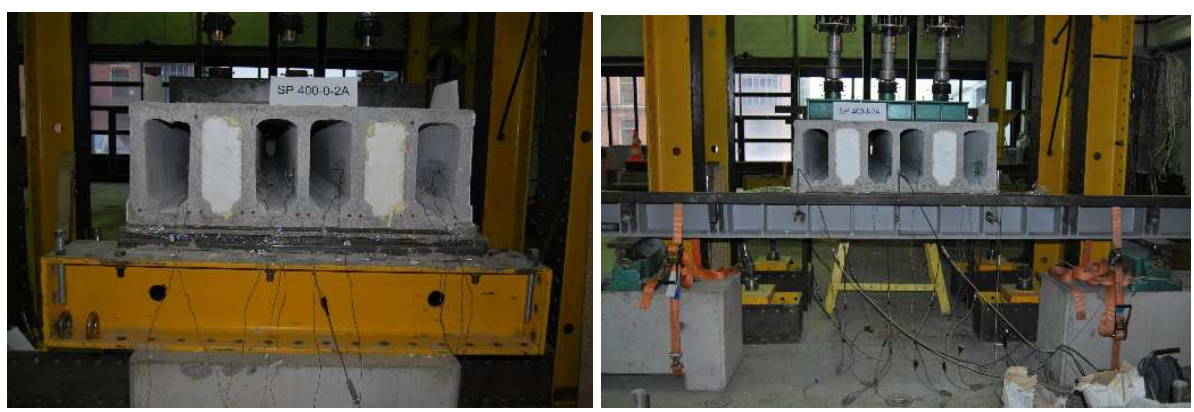

Rys. 4. Widok elementu na stanowisku badawczym a) podpora sztywna b) podpora sprężysta

Fig. 4. Elements view during tests a) non-flexible support b) flexible support 
lony na trzy niezależne odcinki. Aby zapewnić równomierne przekazywanie obciążenia na płytę na całej jej szerokości, górną powierzchnię płyty w obszarze kontaktu trawersu z betonem, wyrównywano zaprawą o wysokiej wytrzymałości. Obciążenie przykładano po minimum 24 godzinach od wyrównania powierzchni. W serii II, obejmującej badanie elementów opartych na podporze odkształcalnej (rys. 4b), sprężystość podpory dobrano w taki sposób aby lokalne wygięcie kształtownika (belki podpierającej), mierzone pomiędzy dwoma skrajnymi punktami na szerokości podparcia płyty $(1200 \mathrm{~mm})$, wynosiło około $2 \mathrm{~mm}$. Uzyskano to dzięki zastosowaniu, jako podpory pod płytę, blachownicy o przekroju dwuteowym i momencie bezwładności $J_{y}=11958 \mathrm{~cm}^{4}$ dla której przyjęto osiowy rozstaw podpór w odległości $3000 \mathrm{~mm}$.

Z uwagi na znacznie mniejszą wartość reakcji od płyty na przeciwległej podporze, przyjmując to samo kryterium odkształcenia ( $2 \mathrm{~mm}$ na długości $1200 \mathrm{~mm})$, zastosowano oparcie na kształtowniku HEB160 $\left(J_{y}=2490 \mathrm{~cm}^{4}\right)$. Charakterystyczne wymiary stanowiska badawczego pokazano na rys. 5 .

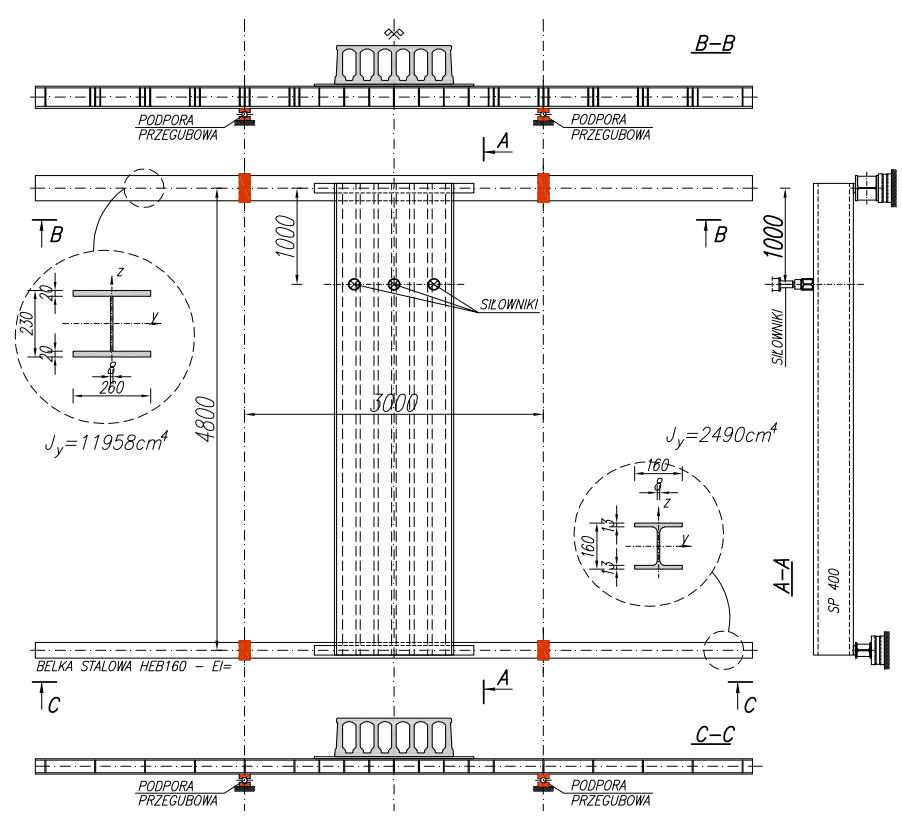

Rys. 5. Widok stanowiska badawczego z podporami sprężystymi

Fig. 5. Test setup on flexible supports

\section{Wyniki badań}

Wszystkie płyty, zarówno na podporach nieodkształcalnych jak i te na odkształcalnych zniszczyły się na ścinanie. W trakcie badań, w żadnym elemencie, nie zaobserwowano rys od zginania. Wartości obciążenia niszczącego dla poszczególnych płyt zestawiono na rys. 3. Widoki poszczególnych elementów po 
zniszczeniu pokazano na rys. 6-7. Zniszczenie elementów na podporze nieodkształcalnej, zarówno dla wariantu $\mathrm{z}$ niewypełnionymi jak $\mathrm{i}$ wypełnionymi przedskrajnymi kanałami, nastąpiło w sposób nagły wraz z pojawieniem się rysy ukośnej od ścinania. W zależności od warunków podparcia obraz rysy niszczącej w poszczególnych elementach był nieco inny. W płytach bez wypełnionych kanałów, rysa ukośna tworzyła płaszczyznę łączącą linię przyłożenia obciążenia z krawędzią podpory (rys. 6a i 7a) i w każdym z żeber nachylona była pod tym samym kątem. W płytach opartych na podporach sprężystych, w żebrach skrajnych, rysa nachylona była pod kątem około $45^{\circ}$ i kończyła się na linii przyłożenia obciążenia (rys. 6b). W pozostałych żebrach (żebra wypełnionych kanałów i żebro środkowe) rysa pochylona była znacznie łagodniej i łączyła punkt przyłożenia obciążenia z krawędzią podpory. Dla płyty z wypełnionymi kanałami i opartej na podporze sprężystej obraz zniszczenia był nieco inny niż pozostałych przypadkach. W pierwszej kolejności pojawiały się zarysowania pionowe dolnej półki skrajnego kanału oraz na styku środnika z półką górną (rys. 8.). Taki obraz zarysowania wystąpił w obu skrajnych kanałach i został zaobserwowany w we wszystkich płytach tej serii. Po pojawieniu się zarysowania nie doszło do zniszczenia elementu a w badaniu nadal obserwowano przyrost obciążenia.

W wyniku zwiększenia obciążenia zarysowaniu ukośnemu uległo skrajne żebro płyty. Proces zarysowania nie był tak nagły jak w przypadku płyt na sztywnych podporach. Rysa w początkowej fazie miała nieznaczną szerokość i w miarę wzrostu obciążenia poszerzała się. W ostatnim etapie badania fragmenty skrajnych żebra powyżej rysy ukośnej wydzieliły się od płyty, a żebra środkowe oraz wypełnione kanały uległy zarysowaniu ukośnemu.

W przypadku płyt na sztywnych podporach wypełnienie kanałów powoduje wzrost nośności na ścinanie o $129 \mathrm{kN}$ co odpowiada jedynie obliczeniowemu przyrostowi nośności i jest zdecydowanie mniejsze niż przyrost nośności wyznaczony na podstawie rzeczywistych wytrzymałości materiałów. W przypadku płyt na podporach sprężystych ten przyrost nośności po wypełnieniu kanałów jest nieznacznie większy i wynosi $148 \mathrm{kN}$, jednak i w ta wartość jest mniejsza niż wynikałoby $\mathrm{z}$ analizy przeprowadzonej dla rzeczywistych wytrzymałości
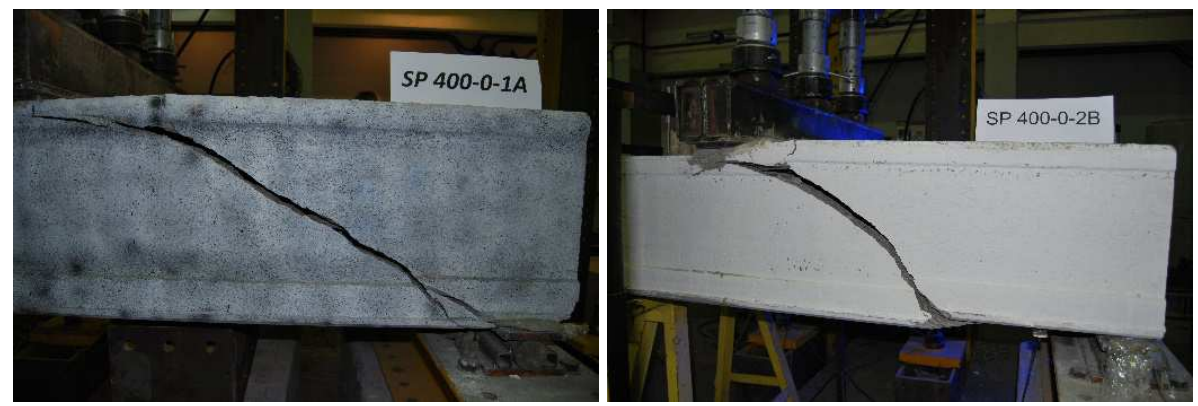

Rys. 6. Widok elementów opartych na podporze nieodkształcalnej po zniszczeniu a) niewypełnione kanały, b) wypełnione kanały

Fig. 6. Elements supported on non-flexible support - view after failure a) empty b) filled hollows 

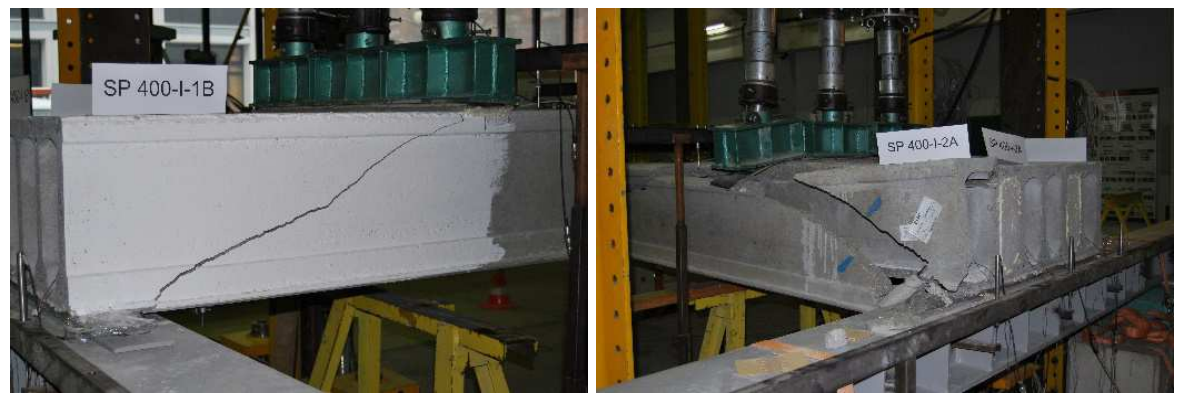

Rys. 7. Widok elementów opartych na podporze odkształcalnej po zniszczeniu a) niewypełnione kanały, b) wypełnione kanały

Fig. 7. Elements supported on flexible support - view after failure a) empty b) filled hollows
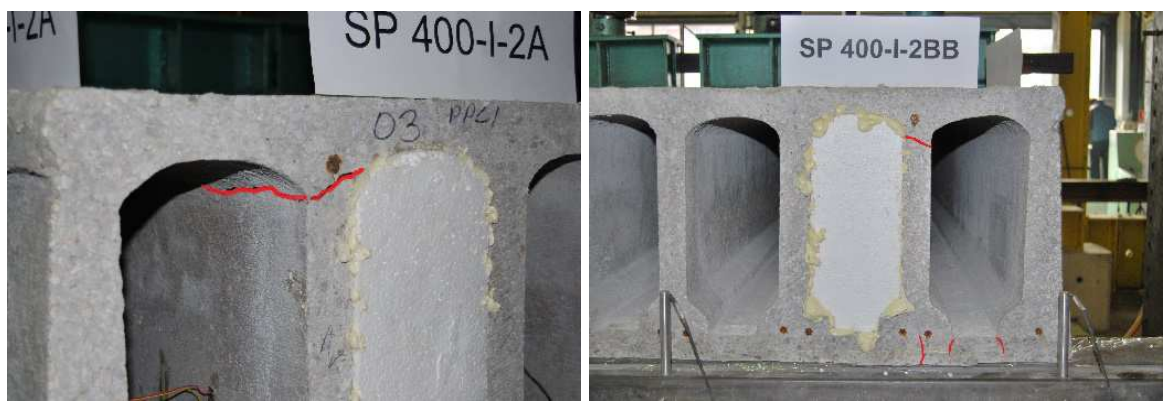

Rys. 8. Zarysowanie w obszarze skrajnego kanału w płytach serii SP 400-I

Fig. 8. Cracks in the area of the outermost hollow - SP 400-I series
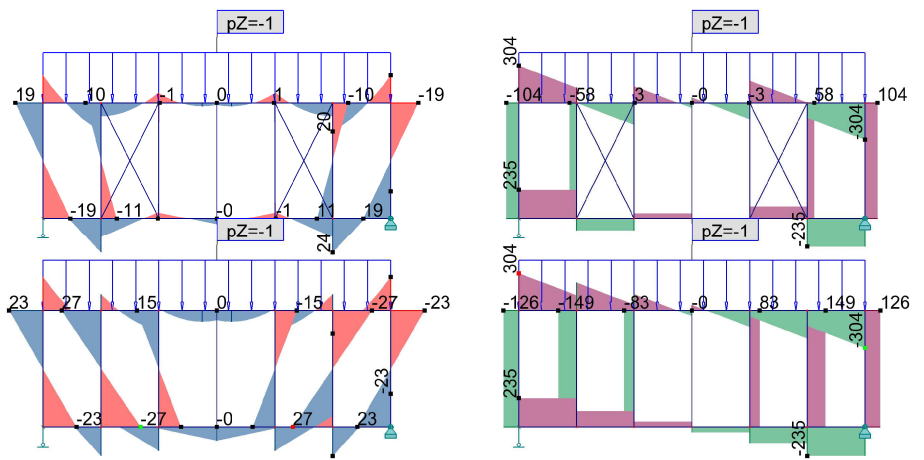

Rys. 9. Układ sił w modelu Vierendeela płyty HC

Fig. 9. Vierendeel's model of HC slab

betonu w kanałach. Potwierdzone zostały również spostrzeżenia z pierwszej serii badawczej dotyczące redukcyjnego wpływu sprężystości podpór na nośność na ścinanie płyt kanałowych. Stwierdzono, że nośność płyty na podporach sprężystych, z wypełnionymi kanałami jest zbliżona do nośności takiej samej płyty bez wypełnienia kanałów badanej na podporach sztywnych. 
Stopień wykorzystania nośności poszczególnych elementów przekroju poprzecznego płyty przeanalizowano stosując model uproszczony w formie belki Vierendeela z obciążeniem jednostkowym. Na podstawie tej analizy stwierdzono, że wypełnienie kanałów powoduje wzrost aż o $20 \%$ wielkości momentów zginających w płytce górnej i dolnej. Maksymalne momenty zginające występują w miejscach pojawienia się rys od czoła płyty.

\section{Wnioski}

Nośność na ścinanie płyt kanałowych opartych na podporach sprężystych jest mniejsza niż wynikałaby to $\mathrm{z}$ analizy normowej. Wypełnienie kanałów zwiększa tę nośność, jednak w stopniu znacznie mniejszym niż wynikałoby to z przepisów normowych. Nośność płyty w wypełnionymi kanałami i opartej na podporach sprężystych jest zbliżona do nośności płyty na podporach sztywnych.

\section{Literatura}

[1] PN-EN 1992-1-1 Eurokod 2. Projektowanie konstrukcji z betonu. Część 1-1: Reguły ogólne i reguły dla budynków.

[2] PN-EN 1163+A3:2011 Prefabrykaty z betonu - płyty kanałowe.

[3] Pajari M., Koukkari H.: Shear resistance of PHC slabs supported on beams I:Tests. J. Struct. Eng. 1998;1051-61.

[4] Hegger J., Roggendorf T., Kerkeni N.: Shear capacity of prestressed hollow core slabs in slim floor constructions. Engineering Structures 31 (2009) 551-559.

[5] FIB Bulletin no 6. Special design considerations for precast hollow core floors. International Fedaration for structural Concrete (fib) January 2000.

[6] Bodzak P., Sowa Ł.: Badania sprężonych płyt kanałowych opartych na podporach sprężystych, 62 Konferencja Naukowo KILiW PAN i KN PZITB BydgoszczKrynica 2016.

[7] Bodzak P.: Wpływ sprężystego podparcia na nośność sprężonych płyt kanałowych, Inżynieria i Budownictwo nr 12/2016.

\section{THE EFFECT OF THE SUPPORT TYPE ON SHEAR CAPACITY OF PRESTRESSED HOLLOW CORE SLABS WITH AND WITHOUT FILLED CORES}

\section{S u m m a r y}

According to the Standard recommendation it is possible to take into account the filling of the hollow core in order to improve shear capacity. Recent test results showed that shear capacity of the hollow core slabs supported on flexible support are much lower in comparison with those resting on non-flexible supports. In the paper experimental tests results of the hollow core slabs with and without filling supported on non-flexible and flexible supports are presented.

Keywords: hollow-core slabs, flexible supports, filled core, shear

Przestano do redakcji: 01.06 .2017 r.

Przyjęto do druku: 01.09.2017 r. 